\title{
Soot contamination of engine oil - the case of a small turbocharged spark-ignition engine
}

The paper presents the results of thermogravimetric tests of engine oil used in a small turbocharged spark-ignition engine. The main observation from the research was a significant soot contamination of engine oil, that appears even at its low mileage. This indicates that also in the case of port fuel injection spark-ignition engine, high particulate matter emissions may occur. A rapid soot contamination of the oil in this engine indicates that the oil change interval should be shortened.

Key words: engine oil, thermogravimetric analysis, soot, particulate matter, spark-ignition engine

\section{Introduction}

Internal combustion engines will be primary drive source for many years, probably decades. Thus, it is clearly important to perform research and development to provide a better understanding of the fundamental processes affecting engine efficiency and the production of undesirable emissions [9].

The combustion of real fuels in a real engine is always imperfect. This results in the presence of incomplete combustion products in the exhaust gas. One of these components is particulate matter (PM), consisting of inter alia soot. Particulates belong to the most harmful components of exhaust gases [11].

Particulate matter emissions are primarily considered from the perspective of diesel engines. The process of reducing particulate emissions in engine exhaust has been going on for many years. For many years as well, PM emissions from passenger cars with spark-ignition engines were not limited at all. Currently, the PM limit applies only to direct injection gasoline engines (GDI) and is the same as for diesel engines (Table 1).

Table 1. European emission standards on PM emissions for passenger cars (category $\mathrm{M}$ ), g/km [2]

\begin{tabular}{|l|c|c|c|}
\hline & $\begin{array}{c}\text { Effective from } \\
\text { (first registration) }\end{array}$ & Diesel & $\begin{array}{c}\text { Spark- } \\
\text { ignition }\end{array}$ \\
\hline Euro 1 & January 1993 & 0.14 & - \\
\hline Euro 2 & January 1997 & 0.08 & - \\
\hline Euro 3 & January 2001 & 0.05 & - \\
\hline Euro 4 & January 2006 & 0.025 & - \\
\hline Euro 5a & January 2011 & 0.005 & $0.005^{*)}$ \\
\hline Euro 5b & January 2013 & 0.0045 & $\left.0.0045^{*}\right)$ \\
\hline Euro 6b & January 2015 & 0.0045 & $\left.0.0045^{*}\right)$ \\
\hline Euro 6c & January 2018 & 0.0045 & $\left.0.0045^{*}\right)$ \\
\hline Euro 6d-Temp & January 2019 & 0.0045 & $0.0045^{*}$ \\
\hline Euro 6d & January 2021 & 0.0045 & $\left.0.0045^{*}\right)$ \\
\hline${ }^{*}$ Applies only to vehicles with direct injection engines \\
\hline
\end{tabular}

Port fuel injection (PFI) gasoline engines are considered to emit little particulate matter. Presented by Liang et al. [7] tests of two Euro 4 cars (the same model) with GDI and PFI engines showed that over the NEDC cycle the PM emission for a car with an MPI engine was $3 \mathrm{mg} / \mathrm{km}$, and for this with a GDI engine as much as $14 \mathrm{mg} / \mathrm{km}$.
Most of the particulate matter (soot) formed in the engine's combustion chamber is removed with the exhaust gases, but some of it is also absorbed in the engine oil. It is easy to notice that as engine oil is used, it changes its color to darker, which is caused inter alia by increase in soot content. There is no doubt that the amount of soot in oil depends both on the intensity of soot formation in the engine's combustion chamber, as well as on the mileage of the oil. Thus, the soot content of engine oil at a given mileage is to some extent an indicator of the tendency of a given engine to smoke. The soot content increases with increasing oil mileage and can reach level of several percent. At this concentration, soot significantly changes (worsens) the lubricating properties of engine oil.

Increasing the soot content in the oil increases engine wear. Results described in [4] show that soot interacts with oil additives reducing the oil's anti-wear properties possibly by abrasive wear mechanism. Ball-on-flat-disk type tests also revealed the increased wear due to the presence of soot. Scanning electron microscope studies of wear scar diameters suggest that soot is abrasive.

Similar research results are presented in [5]. Cumulative wear was more for samples with soot contamination. A negative impact of soot on wear was already observed at $2 \%$ soot in engine oil. Oil samples with low dispersant and high zinc dithiophosphate (ZDP) content performed better than samples having high dispersant and low ZDP concentrations at high soot levels. The reason behind this could be the fact that high dispersant levels together with soot contamination results in lubricant thickening resulting in increased wear.

By worsening the lubrication conditions, soot contained in the oil also increases fuel consumption. Although it is not a very significant impact, it cannot be ignored at present when seeking maximum fuel savings and striving to minimize $\mathrm{CO}_{2}$ emissions. According to [8] low friction lubricants provide fuel savings of around $0.5 \%$.

The aim of the tests described in this article was to check the soot content in the engine oil of a small turbocharged spark ignition engine used in a mini city car. The soot content in this oil will allow concluding on the tendency of this engine to emit particulate matter. It will also indicate if the original oil change interval of $15,000 \mathrm{~km}$ is appropriate taking into account oil contamination. 


\section{Test apparatus and procedures}

The tests were carried out on oil used in a small turbocharged spark-ignition engine driving mini city car Smart. Some technical data and key features of the Smart's engine are shown in Table 2. The tested oil was grade: $5 \mathrm{~W}-30$ ACEA A3/B4 API SL. It was oil designed for engines operating in start-stop mode. Fresh oil and used oils collected after $5000 \mathrm{~km}$ and $8000 \mathrm{~km}$ after oil change were used in the tests. Table 3 shows some key parameters of the fresh oil.

Table 2. Technical data/key features of SMART’s engine

\begin{tabular}{|l|c|}
\hline Engine code & M160 E07 LA \\
\hline Engine type & Spark ignition, in-line three \\
\hline Displcement & $0.698 \mathrm{dm}^{3}$ \\
\hline Bore/stroke & $66.5 \mathrm{~mm} / 67 \mathrm{~mm}$ \\
\hline Compression ratio & 9.5 \\
\hline Maximum power & 96 kW@5250 rpm @2000-4000 rpm \\
\hline Maximum torque & $\begin{array}{c}\text { Single overhead camshaft, } \\
2 \text { valves per cylinder }\end{array}$ \\
\hline Valvetrain & $\begin{array}{c}\text { Multipoint sequential injection, } \\
\text { max injection pressure 4.8 bar }\end{array}$ \\
\hline Injection system & Dual ignition - 2 spark plugs per cylinder \\
\hline Ignition & Turbocharging with intercooling \\
\hline Forced induction & Map-guided \\
\hline Charge air control & Three-way catalytic converter \\
\hline Exhaust aftertreatment & Euro 4 \\
\hline Emissions standard & 3 dm ${ }^{3}$ \\
\hline Engine oil capacity &
\end{tabular}

Table 3. Characteristics of the fresh engine oil [1]

\begin{tabular}{|l|c|c|c|}
\hline Name & Method & Units & Value \\
\hline Density @ $15^{\circ} \mathrm{C}$ & ASTM D4052 & $\mathrm{g} / \mathrm{ml}$ & 0.855 \\
\hline Kinematic viscosity @ $100^{\circ} \mathrm{C}$ & ASTM D445 & $\mathrm{mm}^{2} / \mathrm{s}$ & 12.0 \\
\hline Viscosity, CCS $-30^{\circ} \mathrm{C}(5 \mathrm{~W})$ & ASTM D5293 & $\mathrm{mPa} s$ & 6400 \\
\hline Kinematic viscosity @ $40^{\circ} \mathrm{C}$ & ASTM D445 & $\mathrm{mm}^{2} / \mathrm{s}$ & 73 \\
\hline Viscosity index & ASTM D2270 & - & 161 \\
\hline Pour point & ASTM D97 & ${ }^{\circ} \mathrm{C}$ & -43 \\
\hline Flash point, PMCC & ASTM D93 & ${ }^{\circ} \mathrm{C}$ & 201 \\
\hline Ash, sulphated & ASTM D874 & $\%(\mathrm{~m} / \mathrm{m})$ & 1.3 \\
\hline Grade & \multicolumn{2}{|c|}{$5 \mathrm{C}-30$, ACEA A3/B4, API SL } \\
\hline
\end{tabular}

Thermogravimetric characteristics of oils were determined using a PerkinElmer thermogravimetric analyzer TGA 8000. Thermogravimetric analyzer (abbreviation: TGA) measures the change in mass of the sample as it is heated, cooled, or held at a constant temperature in a controlled atmosphere. Table 4 shows the characteristics of TGA 8000 and Fig. 1 shows the picture of TGA 8000 . Figure 2 presents a sample of the used engine oil just before the start of the test, placed on the autosampler of the TGA 8000 analyzer (visible black oil color).
Thermogravimetric characteristics of the tested oils were determined according to the temperature program based on the temperature program described in the ASTM D5967 standard. ASTM D5967 is a test method which covers engine test procedures for evaluating diesel engine performance characteristics including viscosity and soot concentrations. Annex A4 is a recommendation on how to measure soot in engine oils. Details of the thermogravimetric analyzer working conditions during the tests are presented in Table 5. Pyris software version 13.3.1 was used to analyze the obtained results.

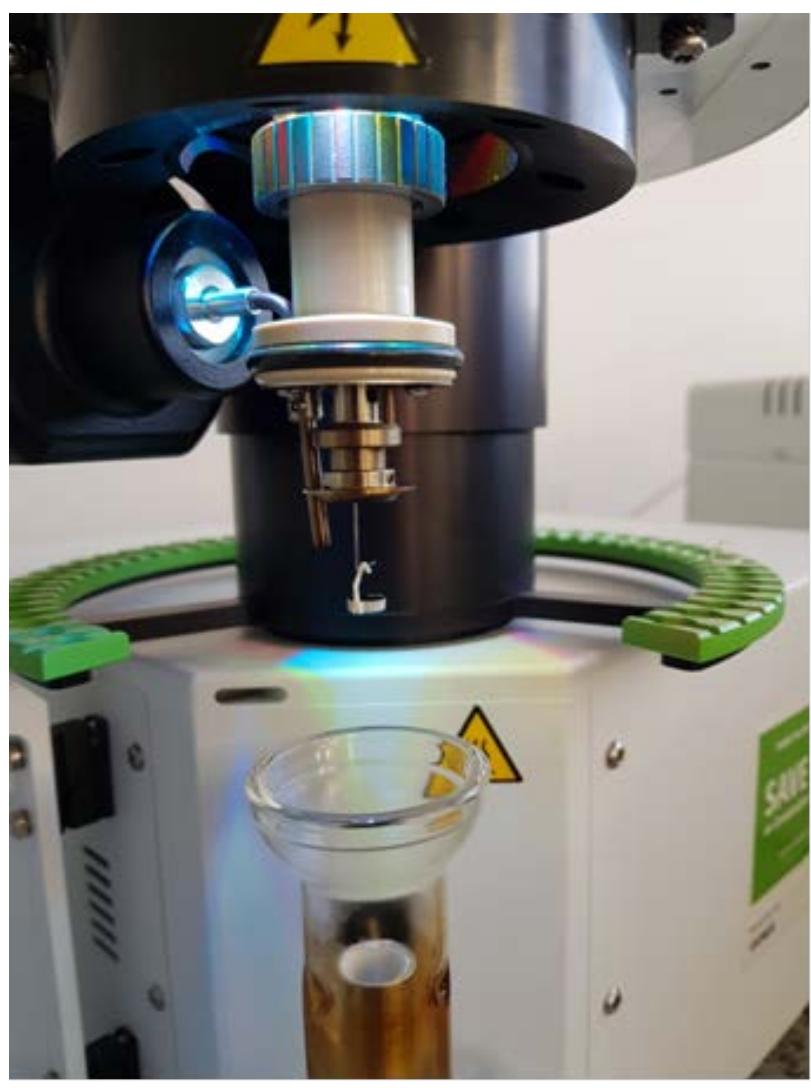

Fig. 1. PerkinElmer thermogravimetric analyzer TGA 8000

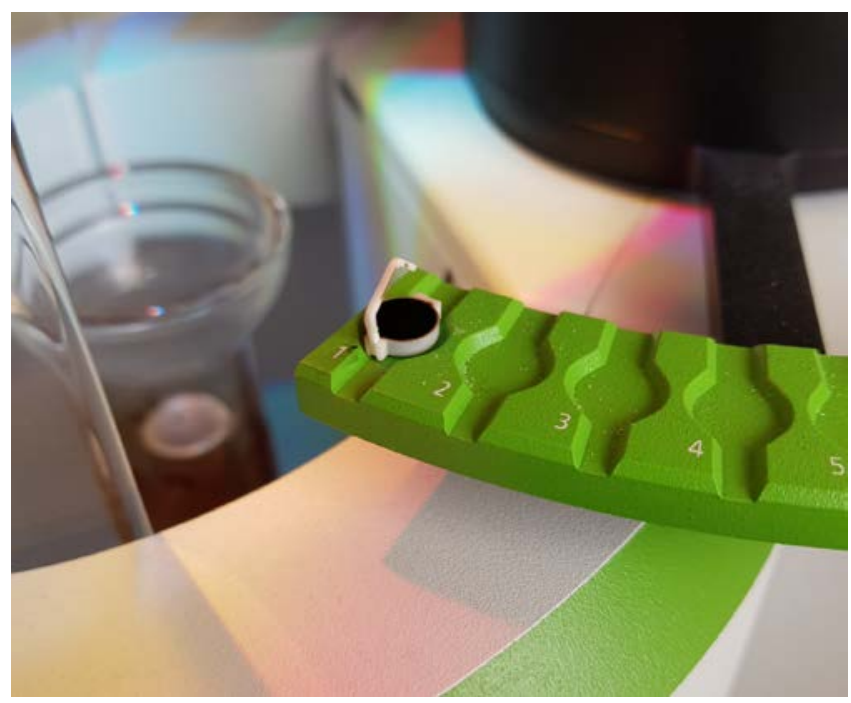

Fig. 2. Sample of used engine oil placed on the autosampler of TGA 8000 analyzer 
Table 4. Specifications of TGA 8000 thermogravimetric analyzer used in the research

\begin{tabular}{|c|c|c|}
\hline Design & & $\begin{array}{l}\text { A vertical design with a high sensitivi- } \\
\text { ty balance and quick response furnace. } \\
\text { The balance is located above the } \\
\text { furnace and is thermally isolated from } \\
\text { it. A precision hang-down wire is } \\
\text { suspended from the balance down into } \\
\text { the furnace. At the end of the hang- } \\
\text { down wire is the sample pan. The } \\
\text { sample pan's position is reproducible. }\end{array}$ \\
\hline \multirow[t]{4}{*}{ Balance } & Sensitivity & $0.1 \mu \mathrm{g}$ \\
\hline & Capacity & $1300 \mathrm{mg}$ \\
\hline & Accuracy & better than $0.02 \%$ \\
\hline & Precision & $0.01 \%$ \\
\hline \multirow[t]{4}{*}{ Temperature } & Furnace & $\begin{array}{l}\text { Low mass }(<10 \mathrm{~g}) \text {; Platinum heating } \\
\text { element with ceramic protective coat- } \\
\text { ing; resistant to inert and oxidative gas } \\
\text { over the full temperature range. }\end{array}$ \\
\hline & Range & $-20^{\circ} \mathrm{C}$ to $1200^{\circ} \mathrm{C}$ \\
\hline & Scan rates & $0.1^{\circ} \mathrm{C} / \mathrm{min}$ to $500^{\circ} \mathrm{C} / \mathrm{min}$ \\
\hline & Precision & $\pm 1^{\circ} \mathrm{C}$ \\
\hline \multirow[t]{2}{*}{ Cooling } & Method & Forced air cooled with an external fan \\
\hline & Cycle time & $1100^{\circ} \mathrm{C}$ to $50^{\circ} \mathrm{C}<13 \mathrm{~min}$ \\
\hline Sample Pans & & Platinum or ceramic (60 $\mu \mathrm{L})$ \\
\hline \multirow[t]{4}{*}{ Atmosphere } & $\begin{array}{l}\text { Sample } \\
\text { environment }\end{array}$ & $\begin{array}{l}\text { Static or dynamic, including nitrogen, } \\
\text { argon, helium, carbon dioxide, air, } \\
\text { oxygen, or other inert or reactive } \\
\text { gases. Analyses done at normal or } \\
\text { reduced pressures. }\end{array}$ \\
\hline & $\begin{array}{l}\text { Gas } \\
\text { control }\end{array}$ & $\begin{array}{l}\text { Balance purge (mass-flow controlled); } \\
\text { Sample purge (switch between } 2 \text { gases; } \\
\text { mass-flow controlled); Reactive purge. }\end{array}$ \\
\hline & Gas mixing & Up to 3 gases \\
\hline & Vacuum & $10^{-5}$ Torr \\
\hline Autosampler & & 48-position \\
\hline
\end{tabular}

Table 5. TGA experimental conditions

\begin{tabular}{|c|c|c|}
\hline $\begin{array}{l}\text { Instrument } \\
\text { conditions }\end{array}$ & $\begin{array}{l}\text { ASTM D5967 } \\
\text { Annex A4 [10] }\end{array}$ & $\begin{array}{l}\text { Conditions applied } \\
\text { in this research }\end{array}$ \\
\hline $\begin{array}{l}\text { Tempera- } \\
\text { ture pro- } \\
\text { gram }\end{array}$ & $\begin{array}{l}\text { 1. Hold for } 1 \mathrm{~min} \text { at } 50^{\circ} \mathrm{C} \\
\text { 2. Heat from } 50^{\circ} \mathrm{C} \text { to } \\
550^{\circ} \mathrm{C} \text { at } 100^{\circ} \mathrm{C} / \mathrm{min} \\
\text { 3. Hold for } 1 \mathrm{~min} \text { at } \\
550^{\circ} \mathrm{C} \\
\text { 4. Heat from } 550^{\circ} \mathrm{C} \text { to } \\
650^{\circ} \mathrm{C} \text { at } 100^{\circ} \mathrm{C} / \mathrm{min} \\
\text { 5. Heat from } 650^{\circ} \mathrm{C} \text { to } \\
750^{\circ} \mathrm{C} \text { at } 100^{\circ} \mathrm{C} / \mathrm{min} \\
\text { 6. Hold for } 5 \mathrm{~min} \text { at } \\
750^{\circ} \mathrm{C}\end{array}$ & $\begin{array}{l}\text { 1. Hold for } 4 \mathrm{~min} \text { at } 50^{\circ} \mathrm{C} \\
\text { 2. Heat from } 50^{\circ} \mathrm{C} \text { to } \\
550^{\circ} \mathrm{C} \text { at } 50^{\circ} \mathrm{C} / \mathrm{min} \\
\text { 3. Hold for } 2 \mathrm{~min} \text { at } \\
550^{\circ} \mathrm{C} \\
\text { 4. Heat from } 550^{\circ} \mathrm{C} \text { to } \\
650^{\circ} \mathrm{C} \text { at } 10^{\circ} \mathrm{C} / \mathrm{min} \\
\text { 5. Heat from } 650^{\circ} \mathrm{C} \text { to } \\
750^{\circ} \mathrm{C} \text { at } 10^{\circ} \mathrm{C} / \mathrm{min} \\
\text { 6. Hold for } 15 \mathrm{~min} \text { at } \\
750^{\circ} \mathrm{C}\end{array}$ \\
\hline Pan type & Platinum & Ceramic \\
\hline $\begin{array}{l}\text { Balance } \\
\text { purge }\end{array}$ & $40 \mathrm{ml} / \mathrm{min}$ & $60 \mathrm{ml} / \mathrm{min}$ \\
\hline $\begin{array}{l}\text { Sample } \\
\text { purge }\end{array}$ & $\begin{array}{l}\mathrm{N}_{2}, 30 \mathrm{ml} / \mathrm{min} \\
\text { for step } 1 \text { to } 4 \\
\mathrm{O}_{2}, 30 \mathrm{ml} / \mathrm{min} \\
\text { for step } 5 \text { and } 6\end{array}$ & $\begin{array}{l}\mathrm{N}_{2}, 40 \mathrm{ml} / \mathrm{min} \\
\text { for step } 1 \text { to } 4 \\
\text { air, } 40 \mathrm{ml} / \mathrm{min} \\
\text { for step } 5 \text { and } 6\end{array}$ \\
\hline $\begin{array}{l}\text { Sample } \\
\text { quantity }\end{array}$ & Around $10 \mathrm{mg}$ & Around $20 \mathrm{mg}$ \\
\hline
\end{tabular}

\section{Test results and discussion}

The thermogram for fresh oil is shown in Fig. 3. Fig. 4, in turn, shows comparative thermograms of fresh oil and used oils - after 5 and 8 thousand kilometers. As can be seen from this comparison, the thermogram curves are similar in all cases, however, the distillation of fresh oil takes place in the narrowest temperature range (the curve is steeper). This confirms the correctness of the measurements carried out. For used oils, it can be seen that the visible weight loss during the thermogravimetric test starts at a lower temperature. This indicates that as oil mileage increases, its fuel contamination increases. At the same time, it is noted that the used oils contain more substances with high boiling points. These substances are the result of oil decomposition at high temperatures in the engine. Fresh oil contains practically no components with a boiling point higher than $450^{\circ} \mathrm{C}$.

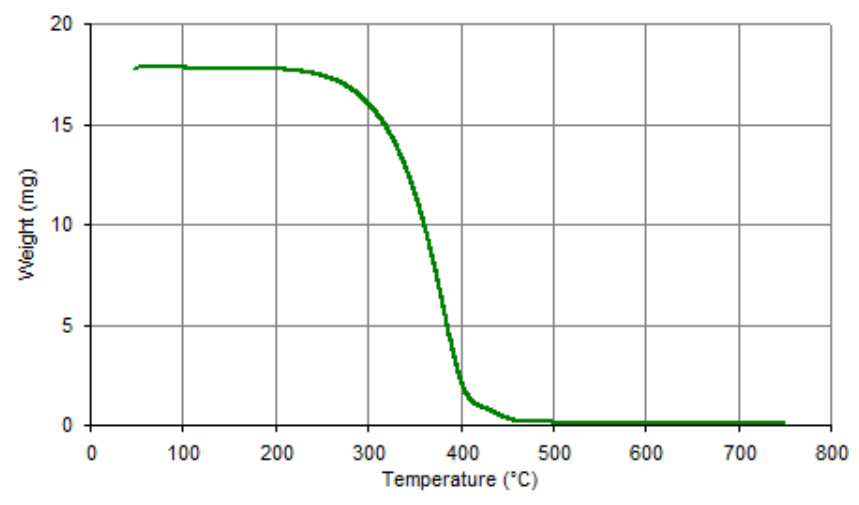

Fig. 3. Thermogram of fresh engine oil obtained during the temperature program presented in the Table 5

The main aim of thermogravimetric tests was to determine the soot content of fresh and used engine oils. Looking at the engine oil thermogram - the first weight loss that occurs as the sample is heated is the evaporative loss of the lubricating oil and any other volatile materials present. All that remains will be soot and other solid residues present in the sample. Switching the purge gas from nitrogen to oxygen or air will remove any soot present in the sample. The calculation of soot content was performed for the weight loss that commences after switching over the purge gas from nitrogen to oxygen or air at $650^{\circ} \mathrm{C}$ up to the temperature where constant residue was obtained around $750^{\circ} \mathrm{C}$ [3].

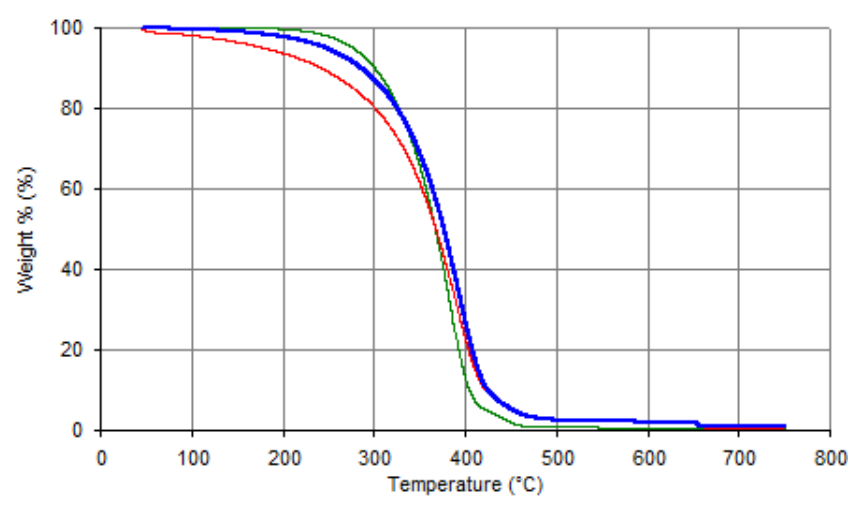

Fig. 4. Comparison of thermograms of fresh (green curve) and used oils (blue curve - mileage of $5000 \mathrm{~km}$ and red - $8000 \mathrm{~km}$ ) 
Figures 5-7 show enlarged parts of the thermograms for fresh and used oils, as well as the decrease in sample mass under conditions of oxidizing atmosphere. This weight loss corresponds to the soot content in engine oil. As can be seen in Fig. 4, fresh oil does not contain any soot at all. Engine oil after $5000 \mathrm{~km}$ already contained about $1 \%$ $(\mathrm{m} / \mathrm{m})$ soot, and after $8000 \mathrm{~km}$ about $1.5 \%(\mathrm{~m} / \mathrm{m})$.

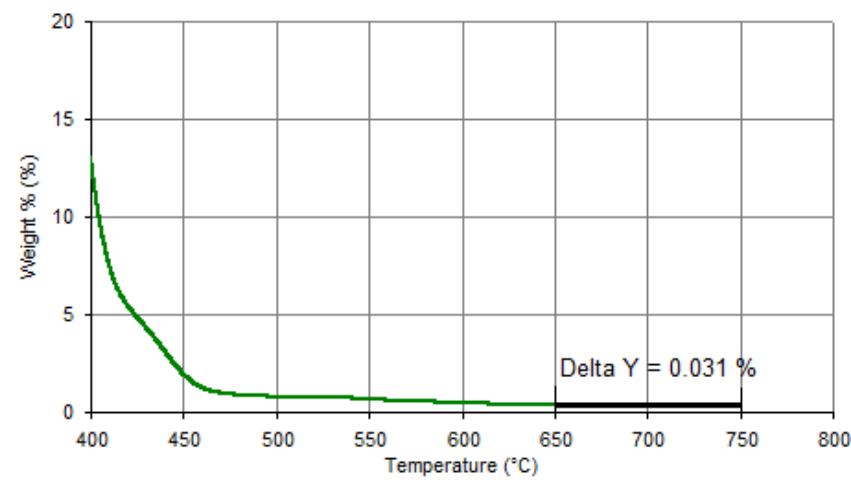

Fig. 5. Thermogram showing percentage soot content in the fresh engine oil sample

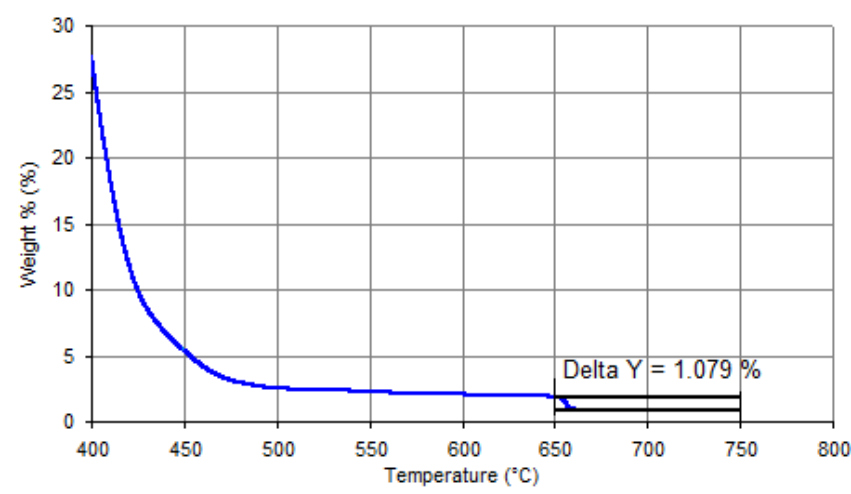

Fig. 6. Thermogram showing percentage soot content in the used engine oil sample (oil mileage: $5000 \mathrm{~km}$ )

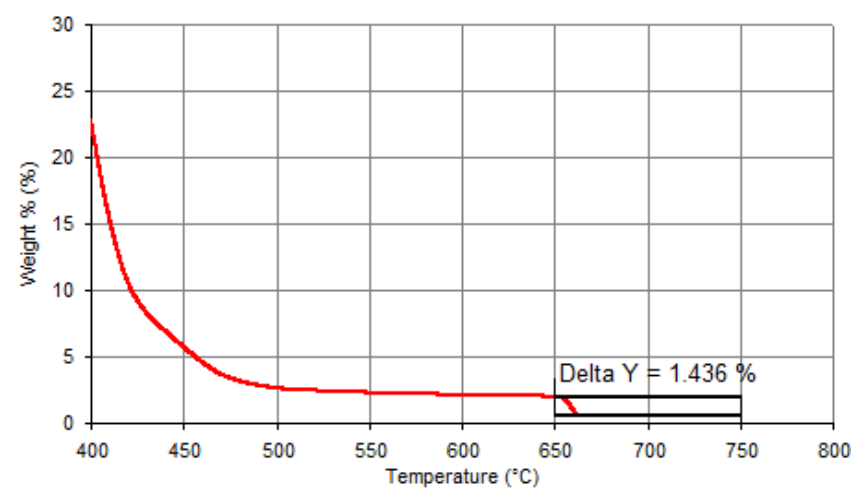

Fig. 7. Thermogram showing percentage soot content in the used engine oil sample (oil mileage: $8000 \mathrm{~km}$ )
It should be pointed out that the soot content found is, for a spark-ignition engine, powered in a PFI system, surprisingly large. The more so that the oil has not yet reached the qualifying mileage for its change $(15,000 \mathrm{~km})$. These values even exceed the soot content of used diesel engine oils. For example, in the tests of oils from four passenger cars with diesel engines presented by Skoczylas [12] it was found that in the case of good technical condition of the engine (low oil consumption), the content of soot in used oil does not exceed $1 \%(\mathrm{~m} / \mathrm{m})$. Similar results were obtained by author for an oil with a mileage of 16,000 km from a turbocharged diesel engine with a capacity of $3.0 \mathrm{dm}^{3}[6]$.

It seems that the main reason for this situation (high soot contamination) was a turbocharger working in the forced induction system of the engine and very dynamic (unfavorable) conditions of engine operation - only urban traffic conditions. It is very important that as it turns out also a spark-ignition engine in good technical condition can be a source of high particulate matter emissions.

Assuming a linear increase in soot content, at 15,000 $\mathrm{km}$ mileage (oil change period) it will be around $3 \%(\mathrm{~m} / \mathrm{m})$. This value is definitely unfavorable when it comes to the oil's lubricating role.

\section{Conclusions}

The results described in this article relate to the determination of thermogravimetric characteristics and soot content in engine oil from a small turbocharged sparkignition engine. It should be noted that the tests described in the article are tests of the oil from one car only. However, the authors do not know any reason that could diminish the credibility of the obtained test results. There was no indication that the engine was in poor condition. The engine did not consume oil. The tests conducted first of all lead to interesting conclusions regarding the content of soot in oil.

Firstly, the spark-ignition engine powered in the PFI system can generate large amounts of soot, and thus emit a large mass of particle matter. It seems that in the present case this is due to the design of the engine and its operating conditions. The results should be verified by measuring PM emissions from this engine, which is a part of the planned further tests. It may therefore turn out that the small city car can be more harmful to the environment than much larger vehicles.

Secondly, another important observation is that the recommended oil change interval - 15,000 km - for this engine (vehicle) is too long. Rapidly increasing soot oil contamination causes deterioration of oil lubricating properties and contributes to increased abrasive wear of the engine. Given the soot content of oil, this period should be reduced by up to half.

\section{Nomenclature}

ACEA European Automobile Manufacturers' Association API American Petroleum Institute

ASTM American Society for Testing and Materials

GDI gasoline direct injection

NEDC New European Driving Cycle
PFI port fuel injection

PM particulate matter

TGA thermogravimetric analyzer

ZDP zinc dithiophosphate 


\section{Bibliography}

[1] Castrol MAGNATEC Stop-Start 5W-30 A3/B4. https://msdspds.castrol.com/bpglis/FusionPDS.nsf/Files/F9C DF2948AC20BD38025838D00576749/\$File/BPXEA7YAVM.pdf

[2] DELPHI Technologies. 2019-2020 Worldwide emissions standards - passenger cars and light duty vehicles. https://www.delphi.com/sites/default/files/2019-05/20192020\%20Passenger\%20Car\%20\&\%20LightDuty\%20Vehicles.pdf

[3] DESHMUKH, P. Soot content determination of in-service lubricants of diesel engine as per ASTM D5967 Annex A4. Perkin Elmer Application Note - Thermal Analysis. https://www.perkinelmer.com/lab-solutions/resources/docs/ APP_Soot_Content_Determination_Diesel_Engine(012934 A_01).pdf

[4] GAUTAM, M., CHITOOR, K., DURBHA, M. et al. Effect of diesel soot contaminated oil on engine wear - investigation of novel oil formulations. Tribology International. 1999, 32(12), 687-699. https://doi.org/10.1016/S0301-679X(99)00081-X

[5] GEORGE, S., BALLA, S., GAUTAM, M. Effect of diesel soot contaminated oil on engine wear. Wear. 2007, 262(9-10), 1113-1122. https://doi.org/10.1016/j.wear.2006.11.002

[6] KOZAK, M. A comparison of thermogravimetric characteristics of fresh and used engine oils. Combustion Engines. 2019, 178(3), 289-292.

https://oi.org/10.19206/CE-2019-350
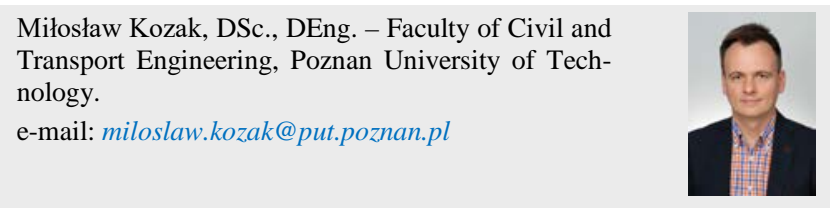

[7] LIANG, B., GE, Y., TAN, J. et al. Comparison of PM emissions from a gasoline direct injected (GDI) vehicle and a port fuel injected (PFI) vehicle measured by electrical low pressure impactor (ELPI) with two fuels: Gasoline and M15 methanol gasoline. Journal of Aerosol Science. 2013, 57, 22-31. https://doi.org/10.1016/j.jaerosci.2012.11.008

[8] NATIONAL RESEARCH COUNCIL. Assessment of fuel economy technologies for light-duty vehicles. The National Academies Press, Washington 2011. https://doi.org/10.17226/12924

[9] REITZ, R. Grand challenges in engine and automotive engineering. Frontiers in Mechanical Engineering. 2015, 1, 1-3. https://doi.org/10.3389/fmech.2015.00001

[10] SATPUTE, Y. Estimation of soot content in engine oil using Thermo Gravimetric Analysis (TGA) as per ASTM D5967 Method. Perkin Elmer Application Note - Thermal Petro. http://www.perkinelmer.com/CMSResources/Images/20130 104_6-Estimation\%20of\%20soot\%20content\%20in\%20 engine\%20oil.pdf

[11] SCHEEPERS, P.T.J., BOS, R.P. Combustion of diesel fuel from a toxicological perspective. International Archives of Occupational and Environmental Health. 1992, 64, 149-161. https://doi.org/10.1007/BF00380904

[12] SKOCZYLAS, W. Thermogravimetric analysis in automotive industry research (in Polish). BSc Thesis, 2019, Faculty of Transport Engineering, Poznan University of Technology.

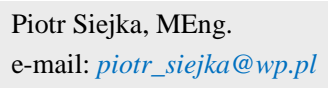

